\title{
Speculative Fetishism
}

Tracy McNulty

Cornell University

Quentin Meillassoux, like his mentor Alain Badiou, is sometimes accused by his critics of "fetishizing mathematics." Without embracing the negative judgment implied in such a charge, this essay asks: what might be gained by taking seriously the link between fetishism and speculative philosophy? The claim that Meillassoux "fetishizes" mathematics potentially reveals something fundamental not only about the formalism at the heart of his speculative realism (whose "glaciality," inanimacy, or inhuman character might sustain a certain disavowal, namely of "finitude" or castration) but about fetishism itself, whose philosophical character is attested not only by its ideality or relation to the absolute, but by its concern with thought or construction. The aim of this essay is thus not to dwell at length on the work of Meillassoux, but rather to think about the "speculative realism" specific to fetishism itself, and its unique contribution to speculative philosophy.

Tracy McNulty is a professor of Comparative Literature and French at Cornell University. She is the author of The Hostess: Hospitality, Femininity, and the Expropriation of Identity (Minnesota, 2007) and of Wrestling with the Angel: Experiments in Symbolic Life (Columbia, 2014). Currently she is working on a new manuscript entitled Libertine Mathematics: Perversions of the Linguistic Turn, to which this essay is related.

Is the fetish a thing? And if so, what kind of thing is it? Is it a thing to be thought? A thing that thwarts or suspends thought? A thing that thinks? What can it tell us about the thought of things?

I ask these questions today not primarily from the perspective of psychoanalytic theory, but at the provocation of the philosophical movement that has done so much recently to foreground the problem of the thing, to put things before us and above all to insist on the priority of things over the consciousness we might have of them: a field of enquiry whose avatars include Object-Oriented Ontology, Speculative Realism, and the New Materialism.

I am thinking in particular of Quentin Meillassoux's critique of philosophical "correlationism," his name for the assumption that our knowledge of things is inherently limited, condemned to "finitude," as a result of its mediation by consciousness-and, ultimately, by the language that structures that 
consciousness. ${ }^{1}$ Meillassoux argues that post-Kantian philosophy has long considered the existence of things only in the guise of givenness, supposing that it is impossible to think the thing-in-itself otherwise than as a thing that exists for us. More specifically, his project takes aim at the legacy of the so-called "linguistic turn" in modern philosophy, and with it the assumption that language alone gives existence to what is, even as this mediation condemns it to loss. $\mathrm{He}$ enjoins his readers to aspire to "achieve what modern philosophy has been telling us for the past two centuries is impossibility itself: to get out of ourselves, to grasp the in-itself, to know what is whether we are or not" (27, emphases in original).

Meillassoux proposes to move beyond the impasses of correlationism by forging a new alliance between philosophy and science, founding his speculative project on a recourse to mathematics in the place of language or consciousness. ${ }^{2}$ In the opening pages of After Finitude, he argues for a rehabilitation of René Descartes' discredited distinction between the "primary" and "secondary" qualities of objects, or between those qualities that are inseparable from the object and qualities that depend on the apprehension of a subject. For Descartes, primary qualities "are all of those properties which pertain to extension and which are therefore subject to geometrical proof: length, width, movement, depth, figure, size" (2). Putting aside extension (which he views as inseparable from sensible representation), Meillassoux proposes "to reactivate the Cartesian thesis in contemporary terms," advancing that

all those aspects of the object that can be formulated in mathematical terms can be meaningfully conceived as properties of the object in itself. All those aspects of the object that can give rise to a mathematical thought (to a formula or to digitalization) rather than to a perception or sensation can be meaningfully turned into properties of the thing not only as it is with me, but also as it is without me.

The thesis we are defending is therefore twofold: on the one hand, we acknowledge that the sensible only exists as a subject's 
relation to the world; but on the other hand, we maintain that the mathematizable properties of the object are exempt from the constraint of such a relation, and that they are effectively in the object in the way in which I conceive them, whether I am in relation with this object or not (2, emphases in original).

What Meillassoux proposes to call "absolute knowledge," therefore-knowledge of the "glacial," "nonhuman," or "ancestral" world—is mathematical knowledge. The "enigma which we must confront," he writes, is "mathematics' ability to discourse about the great outdoors, to discourse about a past where both humanity and life are absent' (26, emphases in original). Mathematics is an inhuman or "ancestral" language, a language that does not require humanity to exist: and that is therefore not afflicted by lack or finitude.

Meillassoux's explicit project is to reunite philosophy and science by proposing a new articulation of what, until now, have been the two extremes of philosophical method, both increasingly marginalized: realism (or empiricism) and idealism (the realm of the absolute). He seeks to understand and to justify the work of the empirical sciences (and thus a certain kind of realism), while at the same time affirming the speculative project of thinking the "absolute" that has traditionally been the purview of philosophical idealism. Mathematics is what guarantees their articulation. Yet critics of Meillassoux's work often charge that its speculative attempt to think the "outside," to get as close as possible to the reality of "what is," either clings to a dogmatic realism (as in the claim that only those objects whose properties can be mathematized really exist) or results in the most abstract idealism. ${ }^{3}$

Some critics, including those who are broadly sympathetic to Meillassoux's project, have expressed reservations about what they find to be its "fetishization of mathematics" (a charge that is often directed against the work of Meillassoux's teacher and mentor Alain Badiou, as well). In charging that Meillassoux "fetishizes" mathematics, they may mean no more in context than that he ascribes exceptional powers to math, or puts too much faith in it as a speculative method. ${ }^{5}$ Whatever the intention, however, I believe that this charge 
rightly identifies his project—and not at all speciously — with another genealogy, to which the charge of "fetishizing" mathematics alludes (however unintentionally): the genealogy of perverse reflection on the real.

What would it mean to take seriously the link with fetishism? In my view, the charge that Meillassoux "fetishizes mathematics" potentially reveals something fundamental not only about the stakes of the formalism at the heart of his speculative realism (whose "glaciality," inanimacy, or inhuman character might sustain a certain disavowal, namely of "finitude" or castration) but about fetishism itself: whose fundamentally philosophical character is attested not only by its ideality or relation to the absolute, but by its concern with thought or construction.

\section{Which Real?}

The attempt to make the real and the ideal coincide, and therefore to bypass correlation (or language and its finitude) altogether, might actually be the very definition of the perverse endeavor. The fetish is the object par excellence that secures this project, since it is a thing that is at once concrete and real (a shoe, braid, undergarment or other object) and purely ideal (the maternal phallus). It attempts to suture the psychical and the physical by lodging in the order of empirical reality an object that only "exists" in the mind, such that the psychical meaning of the object-the endeavor to prove that the maternal phallus really exists-converges with and is sustained by the "realness" of the thing. It joins the real and the ideal as few things do.

The fetish is therefore a thing that has the potential to elucidate better than any other both the potential pitfalls of a speculative realism and its genuine promise. Like mathematics, the fetish gives access to the "thing-in-itself" (in this case the maternal phallus) in a way that is impossible for language, consciousness, and sense perception. In the case of the fetish, of course, this "thing" is also wholly mental. But isn't mathematics also concerned with a purely mental object-not only for Greek ontology, but in its most contemporary iterations? At a minimum, the problem of the mental object engages two different 
ways of thinking about mathematics, one essentially Cartesian (which understands mathematics as the foundation of the scientific method, and thus of empiricism), and the other Platonic (where mathematics is the language of reason, and thus the construction of a supersensible truth).

Some would argue that a fetish is not a thing at all (or at least not a thingin-itself) and therefore not relevant to the project of a speculative realism. But if we exclude the fetish from the order of things, haven't we also given up on an important avatar of thinghood, and with it a crucial dimension of the real? This question goes to the heart of one of the major debates within the object-oriented or speculative realist enterprise, namely the question of which objects or things count as real or can be considered to exist. Tristan Garcia, for example, argues that an object-oriented ontology must consider existence to be an attribute of all things, without exclusion. In his "weak ontology," a fantasy is as much a thing as a rock or a chair, since all objects are equally real-including objects of imagination or delusion. ${ }^{6}$ All things exist, and existence is not merely to be ascribed to those things whose existence can be verified empirically. Meillassoux, on the other hand, excludes objects that exist only for humans from what exists "in itself," whose privileged exemplars are invariably inanimate or "ancestral" realities (for example, the date of the earth's accretion ${ }^{8}$ ), or the socalled "arche-fossils" that indicate their existence.

My aim here is not to dwell at length on the work of Meillassoux (or for that matter of his fellow travelers), but rather to think about the "speculative realism" specific to fetishism itself, and its unique contribution to speculative philosophy.

\section{Perversions of the Linguistic Turn}

This essay is related to a work in progress, provisionally entitled Libertine Mathematics: Perversions of the Linguistic Turn. It seeks to put masterpieces of the libertine tradition by the Marquis de Sade, Leopold von Sacher-Masoch, and the Comte de Lautréamont in dialogue with recent philosophical works that have embraced the language of mathematical formalization—or of other non-signifying 
languages-as a means of contesting the so-called "linguistic turn" in twentieth century thought.

These two series of works are more closely related than they might at first appear, since the devotion to mathematics is a major preoccupation both of libertine literature and of some of its most important authors. Sade and Casanova both authored mathematical treatises of some significance, and Casanova even earned a living as a professor of mathematics when he was not traveling the world seducing the hundreds of virgins he claimed to have deflowered. Richard von Krafft-Ebing, whose Psychopathia Sexualis was the first major work to attempt a taxonomy of the perversions, even identified the predilection for "mathematical patterns" as an essential trait of sadism. ${ }^{10}$ (Gilles Deleuze observes that Sade in particular has a surprising affinity with Spinoza, who arguably belongs to the same genealogy: both rely upon "a naturalistic and mechanistic approach imbued with the mathematical spirit.."11) But what links these libertine and philosophical works, beyond their shared investment in mathematics, is their shared dream of an unmediated confrontation with the real.

In the logic of perversion, the real is always first and foremost the real of the drive. Like the real at stake in mathematics, Deleuze observes that "the death drive cannot be 'given' in psychic life, even in the unconscious, but is essentially silent-which is why we can speak of it only in speculative or mythical terms." ${ }^{12}$ This is why he understands Freud's theory of the death drive not merely as a description of what he observes in the clinic, but as a foray into "speculative philosophy": an attempt to locate a "real" that is not given empirically, and that therefore demands to be constructed.

The ungivenness of the death drive, and the corresponding need to substantiate or construct it, is arguably the central preoccupation of perversion and its most important contribution to the field of psychoanalysis. In seeking to render visible or give voice to the drive, perverse practices can thus be understood as staging a demonstration of what cannot be represented. In so doing, they might also be understood as advancing another understanding of language, which is not opposed to the drive or founded upon the negation of the 
real (Hegel's "the word is the death of the thing"), but a language of the drive: a "language of the real" that is not conditioned by lack or finitude. In Sade's work, the libertine who declares his freedom from the laws that seek to limit the drive also appeals to a new ground of authority in the real, frequently figured as a "voice of nature" that "commands" the libertine to execute its will: an unspoken voice whose authority is not limited by speech, but expressed in the drives and impulses that take hold of the libertine and compel him to act. This "voice" not only speaks in and through the subject whose actions it dictates, but provokes the manifestation of a language that has nothing to do with the finitude and decompletion of human speech. In practices of torture-as in the violent marking or testing of the body in masochistic ritual punishment-the body itself is made to "speak," to give expression to a real that cannot pass through language.

While the libertine's pursuit of an intense and often violent confrontation with the real often entails a great deal of risk, it could also be understood precisely as an attempt to eliminate risk: not only the threat of castration (whose "disavowal" defines perversion, in Freud's lexicon), but more fundamentally the risk that presides over every instance of speech, inasmuch as it involves a mediation (of experience, of the "energy" of the drives, of truth...) by a language that prevents the real from being transmitted in its integrity. Unlike the logics of communication that define instinctual animal languages, and that involve the integral transmission of information from an emitter to a receiver, human speech is always marked by the failure of communication or transmission; it is this risk of failure that the perverse hero of libertine literature seeks to control or even eradicate.

This is where mathematics often comes in, as a language that appears to defy the failure or uncertainty that defines every attempt to represent the real in speech. Sade's libertine philosopher, when he does not explicitly identify himself as an amateur logician or mathematician, at the very least appeals to mathematical reasoning in his diatribes against the "divine chimera," the illusory God of Judeo-Christian theology and his unfounded law. Serge André notes that the libertine's quest for a totalizing language also finds expression in the two 
great passions of Sade the man: for geography - "the system that names and inventories every point on the Earth's great body," in his words-and for mathematics. ${ }^{13}$ In this reading, Sade would appeal to mathematics in an attempt to make visible the Mother's body, to constitute it as a whole. Despite their obvious differences, therefore, mathematics could be said to share with the bodily inscription of the drive in acts of violence or torture the promise of allowing for an integral transmission, the possibility of "speaking all of the real," acceding to the thing-in-itself.

These examples show how mathematics might be understood as having a "fetish" function, that of plugging up a lack on the part of the real. The claim that there is a specifically fetishistic attitude toward language is not in and of itself particularly novel, of course. Jacques Derrida, in his influential elaboration of the logic of the "supplement," even implies that such an attitude is what defines the use of language as such. He deconstructs the classical devaluation of writing (and of linguistic representation more broadly) as a distorting or merely "secondary" representation of the signified-and thus the absenting or negation of an originary presence-by showing how the signifier as "supplement" invariably substitutes or compensates for a lack on the part of the real. What appears as a supernumerary "addition" is thus logically inseparable from the lack that is its condition of possibility.

Jacques-Alain Miller, in his contemporaneous essay "Suture," makes an important contribution to this argument in attempting to prove that the field of mathematical logic is marked by the same equivocal relation to lack that defines every discourse where a subject is at stake. His argument proceeds through a demonstration borrowed from Frege, in which the position of a zero defined as lacking its own identity is shown to condition the serial constitution of numbers. The position of this zero-as-lack is "sutured" by the zero number, which stands in for its absence in the series of numbers. The zero number can therefore be understood as having a "fetishistic" function, inasmuch as it fills in for an absence and so allows the serial constitution of numbers to hold together as a field. ${ }^{14}$ 
Derrida and Miller both understand "fetish" in the sense of "supplement," where the addition of the signifier is called upon to compensate or fill in for an originary lack (recalling Freud's famous dictum concerning the fetish, that a "multiplication of penis symbols always signifies castration"15). This lack is itself a consequence of language, inasmuch as we only access the real-nature or being — by means of the signifier, and so inevitably lose it as a "thing." If it is possible to construct a mental image of a maternal phallus, therefore-an object that does not exist in the world-it is because language, the phallic signifier, causes the female body to be viewed as "lacking," and therefore as needing to be supplemented.

The theory of castration, especially as elaborated in Lacan's reading of Freud, suggests that the real is "not all there," that it is lacking as a result of language.$^{16}$ Castration would thus be the lens through which we perceive the world, as Lacan's formula of the fantasy suggests. This in turn suggests that the theory of castration is a crucial avatar of correlationism. Indeed, "castration" is really a synonym for what Meillassoux calls "correlation," especially in its "strong" version. This is because castration really boils down to mediation, or the loss of the "outdoors" that is the consequence of man's subjection to the signifier.

In disavowing castration, therefore, the fetishist would be disavowing not merely the traumatic discovery of lack in the mother's body, but the structural castration or lack that is the consequence of the human being's entry into the order of the signifier and the finitude it implies. The fetishist, like all perverts, wants to demonstrate that we aren't really afflicted by lack or castration. To the finitude in which the mediation of language entraps us, perversion opposes the logic of the drive: a real in excess of language, which the signifier is unable to name or to limit, that is without beginning and without end, that has no aim and therefore cannot be exhausted. The real it upholds is not the real of the empirical sciences, therefore, but a real that is legible only in relation to the phallic mother of perverse fantasy.

As a theory of finitude, the problematic of castration (and its refusal) arguably must be grappled with in any attempt to refute or bypass finitude. If we 
accept this premise, it suggests an easy response to Meillassoux et al, one that numerous critics have made more or less explicitly: the critic of correlationism is merely disavowing castration, railing against a structural impossibility that can be surmounted only in fantasy. ${ }^{17}$ The analogy with fetishism would thus suggest one way of thinking about the "great outdoors" that is the object of Meillassoux's speculative quest: this "outside" would be a fantasmatic outside, the projection of fantasy into the world, and not merely a concrete or preexisting place or thing that we would perceive imperfectly or in a subjective matter.

\section{The "Thought from Outside"}

On one level, the charge that Meillassoux "fetishizes" mathematics simply underscores the psychical dimension of any attempt to access the real, to think it in its integrity in a way not limited by the "finitude" or lack imposed by language. It reintroduces as essential or unavoidable the dimension of mediation or "correlation."

My point here, however, is not simply to criticize Meillassoux's account of correlationism (and thereby reinscribe it within the "linguistic turn" by showing it to be afflicted by the very finitude it attempts to escape), but rather to suggest that it can fruitfully be inserted within another genealogy, also associated with perversion, that deserves to be taken seriously as more than just a symptom or a pathology. Michel Foucault memorably calls it "the thought from outside." ${ }^{18}$ It is, he writes,

a thought that stands outside subjectivity, setting its limits as though from without, articulating its end, making its dispersion shine forth, taking in only its invincible absence; and that, at the same time, stands at the threshold of all positivity, not in order to grasp its foundation or justification but in order to retain the space of its unfolding, the void serving as its site, the distance in which it is constituted and into which its immediate certainties slip the moment they are glimpsed-a thought that, in relation to our knowledge, 
constitutes what in a phrase we might call "the thought of the outside." 19

A "breakthrough to a language from which the subject is excluded," the "thought of the outside" is an experience that Foucault suggests is "now being heralded at diverse points in culture: in the simple gesture of writing as in attempts to formalize language; in the study of myths as in psychoanalysis; in the search for a Logos that would be like the birthplace of all of Western reason" (149).

But Foucault famously anchors this genealogy in the writings of Sade, describing him as the first writer to lay bare the "thought from outside" by tearing open the bubble in which Western consciousness had progressively interiorized the world:

[T] he first rending to expose the thought of the outside was, paradoxically, the recursive monologue of the Marquis de Sade. In the age of Kant and Hegel, at a time when the interiorization of the law of history and the world was being imperiously demanded by Western consciousness as never before, Sade never ceases speaking of the nakedness of desire as the lawless law of the world. (150)

It is therefore no exaggeration, he argues, to claim that Sade "introduced" the experience of the outside into our thinking: an experience that "was afterward to remain not exactly hidden, because it had not penetrated the thickness of our culture, but afloat, foreign, exterior to our interiority, for the entire time the demand was being formulated, most imperiously, to interiorize the world" (150-151).

Here, as elsewhere, Foucault suggests that the "outside," the desire "to get out of ourselves, to grasp the in-itself," is a preoccupation to which perverse thought has a privileged, if not exclusive, relationship. In addition to Sade, the essay is concerned with the writing of several of Foucault's contemporaries, including Georges Bataille (the visionary of "transgression," 154), Pierre Klossowski (who celebrates "the exteriority of simulacra," 153) and Maurice Blanchot (whose language is effaced "in a silence that is not the intimacy of a 
secret but a pure outside where words endlessly unravel," 152). ${ }^{20}$ They are Sade's heirs not only in wielding "a language from which the subject is excluded" (149), but in their predilection for a certain formalism. Where Sade excels at "deploying structure in its most arithmetical positivity," ${ }^{21}$ their prose is "precise," "rigorous," even (in the case of Blanchot) "geometric" (153).

If "desire"—or what Sade himself calls jouissance—is revealed in his work to be the "lawless law of the world," then it should also be understood as stepping into the place that has long been that of mathematics, for philosophy and for the empirical sciences alike. On the one hand, this might suggest that the drive or jouissance takes the place of mathematics, supplanting or displacing it. On the other, it suggests that the fidelity to the drive manifests itself as a kind of formalism, as a predilection for a language that is "arithmetic" or "geometric," and from which the subject seems to have been excluded.

In heralding this "libertine mathematics," one aim of my own project is to argue for the immense but rarely interrogated importance of libertine or perverse thought for contemporary philosophy, and French philosophy in particular. This is something crucial one has to understand about French thought to realize that its association with perversion is not at all pejorative. In some ways Foucault is the key figure in this intellectual history, the author who really claims perverse thought for philosophy, history and psychoanalysis in myriad works written over a period of thirty years, from The Order of Things to The History of Sexuality to Discipline and Punish. But he is certainly not alone. Some of the most important philosophers of structuralism and post-structuralism in particular draw on this corpus, and not merely in their treatments of sexuality and norms. The problem of "excess" is frequently the frame for this interest in the first half of the twentieth century (notably in the work of Bataille), while the "real" is more often the focus of works produced after the war (especially in the wake of Jacques Lacan).

To mention only a few of the greatest hits, the post-war years witnessed the publication in France of Pierre Klossowski's Sade My Neighbor and The Philosopher Villain (1947), Maurice Blanchot's Lautréamont and Sade (1949), Bataille's The Accursed Share [La Part maudite] (1949) and Literature and Evil 
(1957), Lacan's “Kant avec Sade” (1963), Deleuze’s Présentation de SacherMasoch [Coldness and Cruelty] (1967), Derrida's reading of Bataille in Writing and Difference ("From a Restricted to a General Economy: A Hegelianism without Reserve," 1967), Roland Barthes' Sade, Fourier, Loyola (1971), JeanFrançois Lyotard's Libidinal Economy (1974), and Deleuze's two major collaborations with Félix Guattari, Anti-Oedipus and Thousand Plateaus (1972 and 1980). With few exceptions, these authors are not merely writing about perversion, but writing from the vantage of perverse experience in a way that foregrounds its singular contribution to thought. Today the list only continues to grow, notably with the works of the self-declared pervert-philosophers Slavoj Žižek and Mario Perniola. ${ }^{22}$

These are not only studies of (or by) perverse authors, however, but interventions into fundamental problems of philosophy for which the masterpieces of perverse literature serve as exemplary models and guides. Alain Badiou has argued that the twentieth century was animated by a "passion for the real, ${ }^{23}$ attested by a range of different phenomena: the frequency of wars and revolutionary upheavals, the development of nuclear fission, and even the embrace of "purifying" violence in practices of genocide and ethnic cleansing. The "passion for the real" is defined not merely by the celebration of violence, however, but by a contestation of the order of the signifier and of the representations and grand narratives it supported. One of its most important expressions, he argues, is the confrontation with the real in modern mathematics, which entails the risk of foregoing language and linguistic representation in favor of a formal "construction" of the real that has no imaginary or representational dimension. But it also appears in the premium psychoanalysis places on the confrontation with the death drive as the formative event in the subject's life-a theory for which perverse practices serve as an indispensable precursor and guide by exposing the signifier's inability to limit the real of the drive. In a roughly contemporaneous essay on mathematics and philosophy, Badiou underscores their implicit connection when he declares himself the "one and only genuine disciple" of the Comte de Lautréamont, ${ }^{24}$ the great libertine poet whose passion 
for the real expresses itself both as a fidelity to mathematics and as a masochistic allegiance to the drive in its violent purity. ${ }^{25}$

In one of the most recent contributions to this rich vein of thought, Mario Perniola has even claimed that philosophy should be understood not merely as attuned to perverse thought, but as the ultimate realization of the pervert's quest. Writing of Pasolini's film Salò (an adaptation of Sade's 120 Days of Sodom set in the waning days of Mussolini's fascist regime), he advances that philosophy alone has the capacity of reaching that extreme excess that Pasolini pursues with obstinacy in his film. The sadistic search occurs under the sign of frustration and defeat. One can burn breasts and testicles, pull teeth and eyes, impale, skin and flay to infinity without succeeding in reaching that excess that philosophy achieves with chastity. ${ }^{26}$

Philosophy is the formalization of sadism, a sadism purified of its sensuality (a point Deleuze also makes, in striking similar terms, in Coldness and Cruelty: a book whose argument I will return to momentarily).

As these examples ought to make clear, my characterization of the recourse to mathematics and formalization as "perverse" should not be understood as a dismissive criticism, or especially as implying that such a project is ill-founded, misguided or illusory. To the contrary, the juxtaposition of philosophy and perverse thought is intended not to pathologize philosophy so much as to elevate perversion-and to isolate its real contribution to philosophy. Put another way, I see no reason not to take Sade at his word when he claims (in the title of his most influential work) to be doing philosophy in the bedroom, and not just telling stories or generating pornography.

In reading the works I have just mentioned, it is striking how often the "new" comes up in discussions of perversion. The perversions are arguably the source of all novelty, as the example of the fetish-a radically new object, without precedent in the world-suggests. This way of thinking about the perversionsnot as a "regression" or reversion to an earlier stage in human development, but as the anticipation, inauguration or introduction of the unprecedented or unheard- 
of-is perhaps developed most fully in the work of Lacan, especially in his emphasis on the close relationship between perversion and art. But Freud already anticipated this line of thought when he argued that the boy's curiosity about sex-and more specifically, his urgent desire to know whether the mother is possessed of a penis-might be the origin of his epistemic drive: ${ }^{27}$ and therefore, we might infer, of the "love of knowledge" that philosophy enshrines as its singular project. ${ }^{28}$ I understand this comment not as a denigration or pathologizing of the philosophical quest for knowledge, but rather an insight into the truly philosophical stakes of sexual curiosity-especially in its perverse manifestations.

In the space that remains, therefore, I would like to think about the productive implications-and not merely the potential pitfalls—of philosophy's perverse turn.

\section{Beyond Disavowal: the Fetish as a Construction of the Real}

The standard way of understanding the fetish, as we have seen, is as a disavowal of mediation or "castration." By reinserting this mediation, showing how it is operating there "all the same," we reinscribe the fetish in the logic of the signifier, of castration (psychoanalysis) or of supplementarity (Derrida). Fetishism now describes a general pathology, a generic way of refusing what language does to our relation to the "outside."

Gilles Deleuze offers a completely novel approach to this familiar problematic, however, which allows us to grasp the more profound relation of fetishism to philosophy. It concerns the problem of construction, or the nature of the real or truth that is opposed to a deficient reality; it therefore considers what the logic of perversion seeks to illuminate or make visible, above and beyond what it refuses or strives to disavow. Key to this reading is Deleuze's insight that the fetish actually belongs to the complex of masochism, and to the death drive that masochistic ritual practice seeks to stage and uphold. It shows the fetish to have another function, which is not so easily reduced to the disavowal of 
mediation and that cannot be wholly inscribed within the order of the signifier or language.

In Coldness and Cruelty (1967), his remarkable reading of SacherMasoch's Venus in Furs, Deleuze even argues that masochism is defined by the pursuit of "supersensualism," and not-as one might suppose-of a quest for unbounded sensuality, or the eroticization of pain or suffering. On the face of it, this claim is counter-intuitive. The perverse demonstration seems to aim at an intensification of sensuality, notably through the sensations of pleasure and pain. Even in Sacher-Masoch's novel, Severin appears to swing from masochism to sadism, or between the pleasure taken in receiving pain to the pleasure taken in delivering it.

But while Deleuze admits that the masochistic adventure of Venus is structured by a series of dialectical reversals, he contends that it is not the Hegelian dialectic that holds sway here, but a Platonic "dialectic of the imagination" (22) that aims at the "supersensualism" of the Ideal. He suggests that masochism aims at a specific "freezing" or suspension of the "pendulum swing" between two poles, which are represented in the novel by two different modes of sensuality: the hedonistic ideal of the Greek woman or Aphrodite who dedicates herself solely to the pursuit of pleasure, and the tortures of the sadist. The masochist seeks to identify a specific supersensualism that is pursued inand also beyond-sensual experience. Thematically it is expressed by the ideal of "coldness," which in freezing the warmth of sensuality allows a specific severity to emerge. ${ }^{29}$ The Greek ideal is transformed into the masochistic ideal through "the catastrophe of the glacial epoch, which accounts for both the repression of sensuality and the triumphant rise of severity" (52-3). The Ideal is thus "the specific freezing point, the point at which idealism is realized" (55). Only at this "freezing point" can the masochistic ideal of the "cold mother" exist; only here does the maternal phallus, which has no sensual existence, reveal itself in its timeless eternity, in the form of frozen images, impersonal traits, and inanimate objects. ${ }^{30}$ 
It is here that Deleuze introduces the fetish: not as a compensation for what is missing, but as a support for this supersensual ideal. Deleuze follows Freud in affirming that the fetish is the "image or substitute of the female phallus," and thus "the means by which we deny that a woman lacks a penis." ${ }^{31}$ More importantly, however, it functions as what he calls a "protective and idealizing neutralization." That is, "the belief in a female phallus is itself experienced as a protest of the ideal against the real; it remains suspended or neutralized in the ideal, the better to shield itself against the painful awareness of reality." It follows, Deleuze writes, that "disavowal should perhaps be understood as the point of departure of an operation that consists...in radically contesting the validity of that which is: it suspends belief in and neutralizes the given in such a way that a new horizon opens up beyond the given and in place of it" (31).

(In other words, the fetish substitutes not for a "real" penis, but for the maternal phallus that does not exist in reality: and that for that very reason lays claim to being the ideal or "true" phallus: the one that never fails, that is not subject to castration. As Serge André's perverse patient Violette puts it, a woman is superior to a man because she never loses her erection; only a woman who does not actually "have" a penis can never lose it. ${ }^{32}$ In Platonic terms, we might say that the maternal phallus is the "ideal form," the male penis its "copy." The fetish therefore opposes the Ideal-the maternal phallus that does not "exist"-to the real: the male penis that, by virtue of "existing," is necessarily secondary with respect to the ideal.)

The attainment of this "specific freezing point" thus serves two aims. The first is defensive, where the suspension of movement has the effect of making time stand still-and so freezing the threat of castration in its tracks (31). But the second and more important function of this frozen arrest is to elucidate another reality: that of the maternal phallus, certainly, but in and beyond it the reality of the death drive itself. Here it is important to recall that for Freud, inanimacy is the form in which the death drive is most often expressed in its ungivenness. The formalism of the masochist's surrender to the mother's icy discipline sustains not only a certain maternal ideal, therefore, but the suspension, timelessness and 
inanimacy of the death drive itself. (In Sacher-Masoch's work their interrelation is figured by the "cold steppe" of Mother Russia, a perpetually frozen tundra virtually devoid of life that is nonetheless animated in his writing by the vital energy of the drive.) The relationship between the "cold mother" and the death drive is already implied in Sacher-Masoch's three feminine types, in which Deleuze sees three fundamental mother images: the primitive, uterine mother; the Oedipal mother, figure of the beloved, who becomes linked with the sadistic father as victim or as accomplice; and the oral mother, the mother of the steppe, who nurtures and brings death (55). (Freud, he reminds us, found the same trinity in the Three Fates: "The mother herself, the beloved who is chosen after her pattern, and finally the Mother Earth who receives him again... the third of the Fates alone, the silent goddess of Death, will take him into her arms." ${ }^{33}$ )

This is why fetishism belongs to masochism, and thus to a speculative enterprise. With this argument, Deleuze underscores the profound connection between fetishism and the death drive that is too often ignored by the theoretical literature on the perversions. Indeed, the "supersensualism in and beyond sensual experience" that Deleuze reads as the object of Severin's quest might even be a definition of the death drive, as Deleuze reads it. As a drive to the inorganic, the death drive is fundamentally opposed to sensuality, and specifically to pleasure and pain. This is why Deleuze understands Freud's account of the death drive as the "beyond of the pleasure principle" not in terms of the transgression of a boundary or limit (going "beyond pleasure" into something painful or traumatic, for example), but rather as a foray into speculative philosophy, an attempt to identify the transcendent principle or "higher law" of the pleasure principle, the supersensual law of its sensual manifestations.

The "glacial anti-humanism" that Badiou ascribes to Lautréamont's evocation of math resonates powerfully with this frozen ideal: as if Lautréamont had found in mathematics the "cold mother" who proves so elusive to the masochist in reality. At the same time, the link between fetishism and mathematics suggests not only that mathematics is capable of functioning 
fetishistically or sustaining a disavowal, but that the fetish is a method, a form of speculative thought. Put another way, it implies the fetish is not only a thing to be thought, but a thing that thinks. ${ }^{34}$

\section{Fetishism's Speculative Enterprise: From Maternal Phallus to Death Drive}

Deleuze shows that what Freud calls "perversion," and which has for him a specific fantasy profile, may well be what in another idiom is called "speculative philosophy." In the same spirit, I want to claim not merely that speculative realism is sometimes fetishistic, but more broadly that fetishism is a speculative realism (and deserves to be taken seriously as such). This is not to say that fetishism does not have a disavowing function, but simply to add (with Deleuze) that disavowal does not merely refuse the reality of castration, but also opens up a "new horizon... beyond the given and in place of it." The "glacial epoch" or "specific freezing point" that masochistic suspension seeks to isolate appears as a depiction or construction of the phallic mother, its "making visible," and not just a refusal of lack (what would be "missing" or "absent"). This function of "giving visibility to what cannot be seen" might even be the central contribution of the perversions to human subjectivity, and the dimension of perversion that explains its foundational status in the theory of psychoanalysis. It really underscores the speculative in speculative realism, since it is concerned with an object that cannot be verified and that is not presented to consciousness.

As Deleuze demonstrates so compellingly, this object is the death drive itself, and not merely —as I have suggested so far-the maternal phallus. It is the ability of fetishism (and the perversions more generally) to construct the death drive that elevates it to the level of "speculative philosophy," and not the disavowal of lack or castration. As Freud himself observes, it is the perversions that first "bring to light" the reality of the death drive, making "conspicuous" and "tangible" what would otherwise be "silent" and "imperceptible." ${ }^{35}$ If we think of perversion as a speculative philosophy whose object is the death drive, this 
clarifies both the contribution it makes to philosophy and the philosophical stakes of what seem to be only aberrant or non-normative behaviors.

In stressing its link with the death drive, the perversions reveal that the fantasy of the maternal phallus cannot simply be understood as the child's response to the anatomical makeup of women, and especially to the lack or "castration" it is supposed to perceive there. In other words, the reason the mother is so important to the perversions (and indeed to the human as such) is that the child first encounters the death drive in the mother's body. It is thus the relation of the feminine to the drive that the fetish attempts to stage or formalize, and not merely the presence or absence of the expected penis. As Freud himself suggests in his account of the "three mothers," the mother (and more broadly the feminine) has always served as a figuration of the drive in its unbounded quality. ${ }^{36}$ In offering the maternal phallus as a figuration of the death drive, therefore, the specific contribution of the perversions is to reveal not that woman is castrated, but rather that the drive (in the woman) is not castrated. ${ }^{37}$ That is, the woman embodies the excess in drive, and not its lack, finitude, or negation: a lack that in man is symbolized by the phallus that inscribes the logic of castration in the body as the loss of a part of the living being to the Other of language and of culture.

This is why it is important that the "disavowal of castration" always implies at the same time its avowal or recognition. The link between them is the avowal of the death drive, whose operation is inseparable from the "castration," finitude, or lack that the pervert seeks to elude or overcome: precisely by declaring his fidelity to the drive itself, and not to the signifier that in limiting or erecting a barrier against the drive also functions for the neurotic as a defense against the real. This further suggests that to perceive the female body in terms of the play of presence and absence, lack and supplementation, is to see it not as the pervert does, but through the lens of the signifier-and thus in terms of the logic of repression that characterizes the neuroses (where repression is always repression of the real by the signifier). In contrast, the perverse disavowal of the 
mother's castration contests the primacy of the signifier itself, its claim to mediate and so debar the plenitude of the real.

Because the perversions apprehend the maternal phallus at the most fundamental level (where the drive itself is at stake, and not "woman"), they are also able to render it "cosmic," to sense the movement of the drive in the universe, and not to lodge it at the heart of the family unit as the object of a specific complaint or appeal. The corollary is that the maternal phallus cannot simply be conflated with the child's own mother, or for that matter with any human female. Sade and Sacher-Masoch both find it "in the real," where it is figured as a prehuman or extrahuman reality: in the form of the "cold steppe," or what Sade calls Nature, our "common mother." ${ }^{38}$ Both figures suggest that the maternal phallus might best be considered neither as a substitute penis nor as an infallible or uncastratable super-penis, but instead as a figuration of the "oneness of being," or as the evocation of a thingliness "outside" of human consciousness and its finitude that preexists it or promises to outlast it. As a result, the fantasy of the maternal phallus also breaks down in quite surprising ways the distinction between the animate and the inanimate, the physical and the human.

Perverse discourse often represents the death drive not as an object of human consciousness, but as something that "predates" the human, that is "eternal" or "timeless": an "animate inanimacy" from which life arises and to which it will return, and that life is therefore unable to disturb or limit. It suggests that the death drive might best be understood not as something "internal" to us or that we "experience" (consciously or unconsciously), but rather as the "great outdoors" itself. This possibility is evoked in striking terms by Sade's "Last Will and Testament." It stipulates that his body be buried in an unmarked grave, whose site will then be strewn with acorns to reforest the site of the breach and ensure that "the traces of my grave may disappear from the face of the earth." ${ }^{39}$ Finitude, he suggests, enters the world only with the human, and is solely a matter of human consciousness. Once that consciousness is effaced, its negation negated, what is left is the fullness of the real in its eternity and timelessness. In vanishing from the earth, Sade upholds the completeness of Mother Nature by 
ceding his place to her. This seems to be what Freud himself suggests when he offers the "Nirvana principle" and the "oceanic feeling" as figurations of the death drive. ${ }^{40}$ Both involve the diffusion or absorption of the subject, which gives itself over to the drive in such a way as to "become one" with it.

To stress the psychical function of the "great outdoors" is not to deny that there "really is" a world that precedes the human (and life more generally), an inanimate world. But as Deleuze shows, this inanimacy is itself strangely animate for the pervert, and not merely the physical world of matter. In drawing out this specifically perverse insight into the death drive and its functioning, Deleuze's discussion of the "glacial epoch" heralded by Sacher-Masoch allows us to appreciate something that might otherwise escape attention in the works of Badiou and Meillassoux in particular: the frequency with which they invoke the figures of the "stellar," the "frozen," and-above all-the "glacial." Meillassoux speaks of the glacial as something "ancestral" or pre-human, while for Badiou it is something that Lautréamont and Mallarmé propose to "bring forth"-as in his evocation of a "glacial anti-humanism" whose advent is made possible by mathematics. More than even "cold" (an adjective that really applies only to the experience or perspective of an observer-the sensation of cold ${ }^{42}$-and not to inanimate or non-sentient things like landscapes, planets, or stars), "glacial" in both cases seems to figure a non-human reality, a world that exists apart from our cognition or sensual perception of it. "Glacial" is not a description, that is, but a construction. It seems to evoke the slowing down of movement, the becominginanimate of life or the inanimate vitality of non-living things (the movement of the tectonic plates, the accretion or erosion of geological formations, or the infinitely slow devastation produced by glaciers slicing through land masses). Similarly, Deleuze suggests that the "glacial epoch" that masochistic supersensualism strives to bring forth is one in which life does not disappear altogether, but is "suspended," removed from its natural temporality, made "eternal" or "timeless."

The same could be said of "stellar." It is surely important for Badiou in particular that the star is also a privileged figure of the real for Lacan, as in his well-known claim that the real is the "pole star" of human experience inasmuch 
as it "always returns to the same place." ${ }^{43}$ In stressing that the very constancy, invariability, and inanimacy of the physical sphere is at the same time a figure of repetition, Lacan attempts to capture with the concept of the real a crucial feature of Freud's own theorization of the death drive. In Deleuze's gloss of the same problematic, Freud showed repetition to have two inseparable dimensions. On the one hand,

repetition characterized the binding process inasmuch as it is repetition of the very moment of excitation, the moment of the emergence of life; repetition is what holds together the instant; it constitutes simultaneity. But inseparable from this form of repetition we must conceive of another which in its turn repeats what was before the instant-before excitation disturbed the indifference of the inexcitable and life stirred the inanimate from its sleep. How indeed could excitation be bound and thereby discharged except by this double action of repetition, which on the one hand binds the excitation and on the other tends to eliminate it? Beyond Eros we encounter Thanatos; beyond the ground, the abyss of the groundless; beyond the repetition that links, the repetition that erases and destroys. ${ }^{44}$

In repeating the time "before life stirred the inanimate from its sleep," the repetition at stake in the death drive is less a temporal structure than the effacement of time, since it reveals the time of the "instant" to be a modality of cathexis or binding, the way in which life lays claim to simultaneity or presence.

Unsurprisingly, Meillassoux does not find Deleuze's work as helpful for understanding the project of speculative realism as I have. Instead, he consistently distances himself from Deleuze by accusing the latter of "vitalism." 45 As I have suggested, however, Deleuze in turn contests and complexifies the notion of the "inanimate" or "ancestral" by exposing the vitalist animation of which it is capable. As such, his work is not as far removed from Meillassoux's own project as it might at first appear. In both cases we are dealing not with a vitalism of life, but with what I propose to call a vital formalism: and thus, as Deleuze 
himself suggests, a vitalism that might be understood most productively as an avatar of the death drive. ${ }^{46}$ I have argued elsewhere that Badiou's account of "number" should be understood as a formalization of the drive-not in a purely symptomatic register, but in a way that really does yield something new and enhances our understanding of both. ${ }^{47}$ This "vital formalism" is more or less explicit in Badiou's work, and is pursued with dedication and rigor. Meillassoux, in contrast, is not interested in the drive (or for that matter in any other psychic reality) and as a result precludes any consideration of how it might inform the "great outdoors" he takes as his object.

Meillassoux proposes to "call 'ancestral' any reality anterior to the emergence of the human species-or even anterior to every recognized form of life on earth" (10). The choice of "ancestral" to describe a reality prior to the emergence of life is quite peculiar, however, since the word implies heredity and inheritance (and thus a logic of life). "Ancestral," the dictionary tells us, is an adjective describing what "belongs to or is inherited from ancestors"; alternately, it constitutes "the original type, or an earlier type, whence existing forms are supposed to have developed." "48 This is even more true of "fossil," even if Meillassoux specifies that he "will call 'arche-fossil' or 'fossil-matter' not just materials indicating the traces of past life, according to the familiar sense of the term 'fossil', but materials indicating the existence of an ancestral reality or event; one that is anterior to terrestrial life" (10). Both terms have the effect of animating the inanimate sphere, of introducing a certain vitalism into the pre-organic.

In what sense could a reality anterior to life be conceived as an "ancestor," or as an "original type" from which existing forms would have developed? What strikes me in this choice of terms is not merely the animation they attribute to the inorganic, but their resonance with the peculiar way in which Freud describes the death drive: as a "return" to an inanimate state, which is thereby posited both as the origin or prehistory of life and as its regressive destination. He famously characterizes the drive as the "expression of the inertia inherent in organic life," "an urge...to restore an earlier state of things which the living entity has been obliged to abandon under the pressure of external disturbing forces." ${ }^{\text {" }}$ It follows 
that the goal of life is not "a state of things which has never yet been attained," but rather an "old state of things, an initial state from which the living entity has at one time or other departed and to which it is striving to return by the circuitous paths along which its development leads" (45). These formulations suggest not only that the inanimate is "ancestral" in relation to life, but also that the death drive expresses the inanimacy that is in life, and that (for the human being, at least) even defines life.

\section{Conclusion}

If the fantasy of the phallic mother is not merely the repudiation of an unbearable lack or castration that the mother would embody in a particularly stark or terrifying way, but instead figures the death drive itself, then this also implies that "figure" and "figuration" cease to be solely tropological constructions (predicated upon the play of presence and absence, supplementation and lack), and instead operate in the manner of plastic supports. This pushes figure and figuration into a different sphere, not wholly inscribed within what we generally hold to be the founding assumptions of the "linguistic turn."

My point in highlighting these "perversions of the linguistic turn" is not merely to ironize them, to mark them as impossible or self-defeating, or even to attempt (with Derrida and Miller) to reinscribe them within a logic of the signifier. It is also to suggest that this turn away from the linguistic turn draws attention to a problem that has been there from the very beginnings of rhetoric, that is tied up in the genealogy of figura, and that concerns the plastic potential of figure as something other than a semiotic signifier. ${ }^{50}$ This figure, and this "turn away" [perversio], are uniquely "perverse": not in the sense that they would be deviant or pathological, incapable of assuming lack or negation, or even primarily contestatory or transgressive, but in the sense that they go to the heart of a uniquely perverse insight about language in its relation to the real.

If the fetish is crucial to any consideration of the linguistic turn and its stakes, it is because it is defined avant la lettre by the contestation of its core premises and offers one of the best examples of its "perversion," in every sense 
of the term. This contestation is a disavowal, a fantasy, as even the fetishist himself knows. But it also stages or constructs something to which we might not otherwise have access: the reality of the psychical object-its very claim to be "real," in Lacan's idiom - and at the same time the reality of the death drive itself. It is crucial to distinguish these two different dimensions of the fetish, which go to the heart of the tension within the project of speculative realism. One has to be understood as a mere disavowal of mediation, while the other points to its beyond, its "outside," and its possible construction.

In its special relation to the death drive, the fetish also helps to redefine and to recover the stakes of the real. It reminds us that the real is not simply what is "excluded," what "cannot be represented," and so forth (as the appropriation of the concept of the real in the discourses of cultural studies sometimes suggests). Instead, the real is located or figured only by means of those objects that manage to real-ize, and so force into reality, something that cannot be located empirically. Lacan calls it das Ding, the "Thing," that psychical reality that is located "at the center" of the human universe only as excluded. The real simultaneously structures reality and unsettles its imaginary coherence, producing effects in reality even as it cannot be located there. In this sense its operation is akin to that of phenomena like black holes, or what in physics is called a "strange attractor": something we know by its effects, by the way it warps space-time, even as it eludes detection or empirical observation. We know it not by perceiving it, seeing it, or touching it, that is, but by the way it has warped our perceptions, animated the inanimate, and caused reality to come alive or to burst into flames: as in Van Gogh's eerily vitalist landscapes and natures mortes of tortured sunflowers, alive with jouissance. ${ }^{51}$

Speculative Realism must recognize this fetish, this "thing," and with it a real that is not reducible to a materialism or physicalism. Graham Harman makes a similar point in lamenting the tendency of some authors-including Adrian Johnston and Meillassoux himself-to conceive the project of speculative realism solely in materialist terms, which obliges us "to make a prior decision about what the nature of the real must be: physical matter." In fact, he writes, 
the real will always retain a certain degree of mystery since by definition it is a surplus, something more than any attempt to grasp it or relate to it. To put a premature end to this mystery by polemically asserting certain features that must belong to the real (mass, inertia, extendedness, and so forth) is to replace the real by our own model of the real. There is no better name for this strategy than idealism, as Bruno Latour has argued effectively enough. We can see Meillassoux's idealism not only in his failed attempt to distinguish between absolute idealism and strong correlationism, but also in his view that the primary qualities of things are those that can be mathematized: as if the things-in-themselves were fully translatable into our knowledge of them. ${ }^{52}$

Perversion is a speculative realism, and it allows us to construct something that these other philosophies avoid only at the expense of drastically limiting and reducing the very notion of the thing: the psychic object. Harman and Tristan Garcia are exceptions in this regard, rightly affirming that if we really want to have an ontology centered on objects, it must extend to all objects: and not merely those that could be objects of observation for the empirical sciences or whose properties could be mathematized. Garcia in particular includes the mental within the project of object-oriented ontology, and thereby shows that the promise of this line of work might also be to legitimate and to take seriously the "thinghood" or realness of objects previously dismissed as illusory or fictive. In so doing, he reminds us that an object-oriented ontology need not be a physicalism.

Freud famously concludes his 1933 lecture "The Question of a Weltanschauung" by declaring that psychoanalysis should by rights belong to the Weltanschauung of science, since any science worthy of the name would also deal with the mind and the mental. Science has failed to live up to this promise, and it is imperative that speculative realism not make the same mistake if it is serious about promoting a thought of the real. 
${ }^{1}$ Quentin Meillassoux, After Finitude: An Essay on the Necessity of Contingency.

${ }^{2}$ This argument is taken further in The Number and the Siren, which purports to unlock the mystery of Stéphane Mallarmé's masterpiece Un coup de dés by discerning in the poem a numerical code. Commenting what he holds to be the key verse of Un coup de dés-"the Unique number that cannot be another"Meillassoux argues that the "unique number" could not belong to the contingency of language, which cannot lay hold to the universal because its meter cannot always be transposed into other languages. If Mallarmé "had identified the Number with 12," he writes, "he would simply have returned to the aporia of Igitur by arbitrarily choosing one of the options he had earlier rejected. For to affirm resolutely the value of 12 is still to dream of the perfect alexandrine; but this alexandrine would be but the result of chance, and not its negation. The chance, firstly, of the French language, which, like every determined language, according to Mallarmé, is 'imperfect'-lacking any necessary link between its sounds and its significations. That French should be one language among others betrays its contingency, its babelian curse, and demonstrates that the privileged number of its poetry has no universal status, its alexandrine not always being transposable into foreign poems." The Number and the Siren: A Decipherment of Mallarmé's Coup de dés, 33. Number would accomplish what verse has heretofore failed to do, overcoming the contingency of language and managing at last to formalize what it is unable to say.

3 Johnston, "Hume's Revenge" 112; Graham Harman, “Johnston's Materialist Critique of Meillassoux," 40.

${ }^{4}$ Ray Brassier, "Speculative Realism: Presentation by Ray Brassier"; Adrian Johnston, “Hume's Revenge: À Dieu, Meillassoux?," 105-6.

${ }^{5}$ This is, of course, arguably the essence of fetishism: at least for some of the thinkers who have made use of the concept, including Marx.

${ }^{6}$ Tristan Garcia, Form and Object: A Treatise on Things (Speculative Realism).

7 "I will call 'ancestral' any reality anterior to the emergence of the human species-or even anterior to every recognized form of life on earth" (10.

8 "Empirical science is today capable of producing statements about events anterior to the advent of life as well as consciousness. These statements consist in the dating of 'objects' that are sometimes older than any form of life on earth. These dating procedures were called 'relative' so long as they pertained to the positions of fossils relative to one another (they were arrived at mainly by studying the relative depths of the geological strata from which the fossils were excavated). Dating became 'absolute' with the perfection of techniques (basically in the 1930s) that allowed scientists to determine the actual duration of the measured objects. These techniques generally rely upon the constant rate of disintegration of radioactive nuclei, as well as upon the laws of thermoluminescence- the latter permitting the application of dating techniques to the light emitted by stars" (9).

9 "I will call 'arche-fossil' or 'fossil-matter' not just materials indicating the traces of past life, according to the familiar sense of the term 'fossil', but materials indicating the existence of an ancestral reality or event; one that is anterior to 
terrestrial life. An arche-fossil thus designates the material support on the basis of which the experiments that yield estimates of ancestral phenomena proceedfor example, an isotope whose rate of radioactive decay we know, or the luminous emission of a star that informs us as to the date of its formation" (10). 10 Psychopathia Sexualis, 208-209.

${ }^{11}$ Gilles Deleuze, Coldness and Cruelty, in Masochism, 20.

12 Coldness and Cruelty, 30. Subsequent citations from the same text will be given as page numbers in parentheses.

${ }^{13}$ Serge André, L'imposture perverse, 29.

14 The different stakes of the zero number and of zero-as-lack might be understood as enumerating two different approaches to mathematics and "integral transmission" in the authors I look at, who alternately appeal to logic and mathematics as a means of "monstrating" or formalizing the lack in language or as a solution or alternative to it.

${ }^{15}$ Freud, "Medusa's Head," Sexuality and the Psychology of Love, 202.

${ }^{16}$ In other words, there is no organic lack in the living body: the mother's "castration" is a psychical reality, accessible only to the human; but at the same time, there is no access for the human to the unlacking real of the body.

17 Jacques Lezra, for example, recently suggested to me an interesting take on the relationship between object-oriented ontology and fetishism. The fetishist, he claims, has a complicated relation to the individuality of the fetishized object. One specific shoe provoked the choice of the fetish. Yet any shoe will produce or sustain it, and it can be found everywhere. The fetishist, however, does not see the particular. Instead the generic and the individual are sutured by the object, such that it is no longer just a shoe, but the shoe as a class. Object-oriented ontology is fetishistic, he claims, because it wants that suture for every object. It is based on a disavowal of mediation, like all fetishism. If the fetishist wanted to address this fetishism, to work on it, he would have to come up against this difference. This is why the fetish has to be kept secret. The immediacy is a fantasy, and he knows it; but the fetishist wants at all cost not to destroy that fantasy. (Lezra made these points in the discussion following a talk he presented at Cornell University on November 11, 2014, "Grounds for Materialism," in response to a question I asked about the place of the fetish in his account of materialism, which he described as closely bound up with the problem of the simulacrum.) As an attempt to suture the generic and the particular, the element and the class, fetishism in Lezra's gloss appears as a kind of category error. By extension, the speculative enterprise that shares its fantasy would be less a mathematical statement about the real than a logical fallacy. This is why Lezra denounces the writers associated with this project as "ontological primitives," and distinguishes their work from what he holds to be the much more interesting ontology of Badiou.

${ }^{18}$ La pensée de l'extérieur. Faubion's edition translates Foucault's expression with "the thought of the outside," although the genitive could be read either "of" or "from": the second seems to me to better capture the sense of Foucault's argument. 
19 "The Thought of the Outside," in Aesthetics, Method, and Epistemology, 149. Subsequent citations from the same text will be given as page numbers in parentheses.

20 "When language arrives at its own edge, what it finds is not a positivity that contradicts it but the void that will efface it. Into that void it must go, consenting to come undone in the rumbling, in the immediate negation of what it says, in a silence that is not the intimacy of a secret but a pure outside where words endlessly unravel" (152)

21 "Conversazione con Michel Foucault," 1967 interview with Paolo Caruso. Cited by James Miller, The Passion of Michel Foucault, 154.

${ }^{22}$ See in particular The Pervert's Guide to Cinema, Parts 1, 2, and 3, presented by Slavoj Žižek (DVD, directed by Sophie Fiennes) and The Pervert's Guide to Ideology, presented by Slavoj Žižek (DVD 2013, directed by Sophie Fiennes), and Mario Perniola, The Sex Appeal of the Inorganic.

${ }^{23}$ Alain Badiou, The Century.

24 "Mathematics and Philosophy: The Grand Style and the Little Style," in Alain Badiou, Theoretical Writings, 12.

${ }^{25}$ I have written about both pieces in "The New Man's Fetish," published in The Southern Journal of Philosophy.

${ }^{26}$ Mario Perniola, The Sex Appeal of the Inorganic, 24.

27 "The Sexual Enlightenment of Children," The Standard Edition of the Complete Works of Sigmund Freud Volume IX, ed. James Strachey (London: The Hogarth Press, 1955), 134ff.

${ }^{28}$ Deleuze's reading of Plato's dialogue The Sophist would be relevant here. In his reading of the sophist who challenges Socrates-and through him the ontological doctrine of Parmenides-by introducing the problem of the simulacrum (that which neither is nor is not) suggests that it is neither of these greats who founds philosophy, but the sophist himself ("Plato and the Simulacrum," Logic of Sense, 253-266). Deleuze himself may be the greatest of the modern pervert-philosophers, the one who has taken the furthest the philosophical program of perversion.

29 "The function of the masochistic ideal is to ensure the triumph of ice-cold sentimentality by dint of coldness. The coldness is used here, as it were, to suppress pagan sensuality and keep sadistic sensuality at bay. Sensuality is disavowed, and no longer exists in its own right; thus Masoch can announce the birth of the new man 'devoid of sensual love'" (52).

30 "The scenes in Masoch have of necessity a frozen quality, like statues or portraits; they are replicas of works of art, or else they duplicate themselves in mirrors (as when Severin catches sight of his own reflection in the mirror") (69).

${ }^{31}$ Note that suspension, and the suspension of time in particular, plays a crucial role in this disavowal. In Deleuze's words, "The fetishist's choice of a fetish is determined by the last object he saw as a child before becoming aware of the missing penis (a shoe, for example, in the case of a glance directed from his feet upward). The constant return to this object, this point of departure, enables him to validate the existence of the organ that is in dispute. The fetish is therefore not 
a symbol at all, but as it were a frozen, arrested, two-dimensional image, a photograph to which one returns repeatedly to exorcise the dangerous consequences of movement, the harmful discoveries that result from exploration; it represents the last point at which it is still possible to believe" (31).

32 In André's words, "her true identification is with a phallic mother with respect to whom all men, beginning with the father, are castrated" (L'imposture perverse 126); for this fetishist, therefore, castration "is located on the side of man and the father, rather than on the side of woman and the mother" (129).

33 "Theme of the Three Caskets."

34 Perniola is also an important case here: fetishism is about being "felt" by an object. It therefore attributes a kind of agency or even subjectivity to the thing. 35 "It was not easy...to demonstrate the activities of this supposed death drive. The manifestations of Eros were conspicuous and noisy enough. It might be assumed that the death drive operated silently within the organism toward its dissolution, but that, of course, was no proof. A more fruitful idea was that a portion of the drive is diverted towards the external world and comes to light as a drive of aggressiveness and destructiveness. In this way the drive itself could be pressed into the service of Eros, in that the organism was destroying some other thing, whether animate or inanimate, instead of destroying its own self. At the same time one can suspect from this example that the two kinds of instinct seldom-perhaps never-appear in isolation from each other, but are alloyed with each other in varying and very different proportions and so become unrecognizable to our judgment. In sadism, long since known to us as a component instinct of sexuality, we should have before us a particularly strong alloy of this kind between trends of love and the destructive instinct; while its counterpart, masochism, would be a union between destructiveness directed inwards and sexuality-a union which makes what is otherwise an imperceptible trend into a conspicuous and tangible one." Civilization and its Discontents, 7778; translation modified to put "drive" in the place of "instinct" as a translation for the German Trieb.

36 "The Theme of the Three Caskets."

37 The fantasy of the maternal phallus supports the real of the drive and the specific modality in which the pervert experiences it, in the unlimited or "uncastrated" character of a (maternal) demand that is not mediated or limited by the phallic signifier. The fetish could thus be understood as the figuration of the potency and excess of the death drive, its urgent and superegoic command. The substance of that command is that the subject itself disappear, give itself over entirely to the drive, and thereby "complete" the Mother by ceding its place to her. ${ }^{38}$ Marquis de Sade, La philosophie dans le boudoir (Paris: Gallimard Folio, 1976), 129. These attempts to "positivize" the drive must themselves be regarded as particular fantasies, and thus a particular way of denying or refusing castration (by associating the drive with an energetic potency or plenitude). Nevertheless, they have the effect of "forcing" into consciousness a reality that would otherwise be "indiscernible," as Freud puts it, and therefore at risk of being denied 
altogether (as the neurotic's attempt to negate or contain the real by means of the signifier would suggest).

${ }^{39}$ Marquis de Sade, "Last Will and Testament," in Justine, Philosophy in the Bedroom, and Other Writings, 157.

40 Beyond the Pleasure Principle 67.

${ }^{41}$ Interestingly, both Badiou and Meillassoux take this language from Mallarmé, whose poetry-and not the science that would allow for the investigation of prehuman "arche-fossils," is explicitly identified-by Badiou at least-as the source of their investment in the "glacial" or "inhuman."

42 Meillassoux makes the same point himself in After Finitude (11-12).

43 The Seminar of Jacques Lacan Book VII: The Ethics of Psychoanalysis, ed. Jacques-Alain Miller, 75.

44 Masochism, 114.

45 After Finitude, 37.

${ }^{46}$ One of the major contributions of Coldness and Cruelty is its attempt to differentiate between sadism and masochism, and the different figurations of the drive they offer. If sadism is defined by its investment in the motion, force, and destructive "energy" of the drive, an energy that is invariably conceived in thermodynamic terms, masochism relies instead upon formality and formalization (hence the importance in Sacher-Masoch's fiction of written contracts, frozen statues, paintings and photographs).

47 "The New Man's Fetish."

48 "Ancestral," Oxford English Dictionary.

49 Beyond the Pleasure Principle, 43.

50 This genealogy is brilliantly explored by Erich Auerbach in his seminal essay "Figura." Time, History, and Literature: Selected Essays of Erich Auerbach, 65113.

51 This idea of the inanimate "coming to life" as an experience specific to perversion is explored in an interesting way by Anne Rice's Interview with the Vampire, where the victim's exchange of blood with the vampire whose bite would otherwise be mortal not only allows him to be "undead," to become a vampire in his turn, but to participate in the specific vitalism of the death drive. In the film based on the book this is figured by the new vampire's sudden awareness that the stone statues around him are possessed of agency, or that the landscape is writhing with potential energy or oozing blood: a vitalism that was imperceptible as long as the vampire was merely alive or human.

52 “Johnston's Materialist Critique of Meillassoux," 40-41.

Works Cited

André, Serge. L'imposture perverse. Paris: Seuil, 1993. 
Auerbach, Erich. Time, History, and Literature: Selected Essays of Erich Auerbach, ed. James I. Porter, trans. Jane O. Newman. Princeton: Princeton University Press, 2014.

Badiou, Alain. Theoretical Writings, ed. and trans. Ray Brassier and Alberto Toscano. London: Continuum, 2004.

- The Century, trans. Alberto Toscano. Cambridge: Polity Press, 2007.

Brassier, Ray. "Speculative Realism: Presentation by Ray Brassier." Collapse: Philosophical Research and Development, 3 (November 2007): 306-449.

Deleuze, Gilles. Coldness and Cruelty, in Masochism, trans. Jean McNeil. New York: Zone Books, 1989. 9-138.

- Logic of Sense, trans. Mark Lester. New York: Columbia University Press, 1990.

Foucault, Michel. Aesthetics, Method, and Epistemology, ed. James D. Faubion. New York: The New Press, 1998.

Freud, Sigmund. Beyond the Pleasure Principle, trans. and ed. James Strachey. New York: W.W. Norton \& Co., 1961.

- Civilization and its Discontents, trans. and ed. James Strachey. New York: W.W. Norton \& Co, 1961.

- Sexuality and the Psychology of Love, ed. Philip Rieff. New York: Collier Books, 1963.

Garcia, Tristan. Form and Object: A Treatise on Things (Speculative Realism), trans. Mark Allan Ohm and Jon Cogburn. Edinburgh: Edinburgh University Press, 2014.

Harman, Graham. "Johnston's Materialist Critique of Meillassoux." Umbr(a): A Journal of the Unconscious (2013), 29-48.

Johnston, Adrian. "Hume's Revenge: À Dieu, Meillassoux?," in The Speculative Turn: Continental Materialism and Realism, ed. Levi Bryant, Nick Srnicek, and Graham Harman. Melbourne, re.press, 2011. 92-113.

Krafft-Ebing, Richard von. Psychopathia Sexualis, trans. Domino Falls. London: Velvet Publications, 1997.

Lacan, Jacques. The Seminar of Jacques Lacan Book VII: The Ethics of Psychoanalysis, ed. Jacques-Alain Miller, trans. Dennis Porter. New York: W.W.Norton \& Co., 1992. 
McNulty, Tracy. "The New Man's Fetish." The Southern Journal of Philosophy, 51, Spindel Supplement, "Freudian Futures" (2013): 17-39.

Meillassoux, Quentin. After Finitude: An Essay on the Necessity of Contingency, trans. Ray Brassier. London: Continuum, 2008.

- The Number and the Siren: A Decipherment of Mallarmé's Coup de dés, trans. Robin Mackay. London and New York: Sequence Press, 2012.

Miller, Jacques-Alain. "Suture." Cahiers pour l'analyse 1 (janvier-février 1966): 39-51.

Miller, James. The Passion of Michel Foucault. New York: Simon \& Schuster, 1993.

Perniola, Mario. The Sex Appeal of the Inorganic, trans. Massimo Verdicchio. New York: Continuum, 2004.

Sade, Marquis de. Justine, Philosophy in the Bedroom, and Other Writings, trans. Richard Seaver and Austryn Wainhouse. New York: Grove Press, 1965. 